\begin{tabular}{ll}
\hline \hline MINING AND METALLURGY INSTITUTE BOR & ISSN: 2334-8836 (Štampano izdanje) \\
UDK: 622 & ISSN: 2406-1395 (Online) \\
\hline \hline
\end{tabular}

\title{
SELECTION THE OPTIMUM METHOD OF REHABILITATION THE DEGRADED AREAS AROUND THE BOR RIVER DOWNSTREAM FROM THE FLOTATION TAILING DUMP BOR ${ }^{* * *}$
}

\begin{abstract}
The problem of water and soil pollution in coastal of the Bor River downstream from the Flotation tailing dump Bor dating back to the seventies of the last century. This work gives a selection of optimal method for rehabilitation of degraded areas of the Bor River coast. The four possible methods were discussed for rehabilitation of degraded areas, and the choice of the best was done using a multi-criteria analysis. In addition, the Electra method was used that allowed the selection of optimal rehabilitation methods taking into account the five criteria that cover the most important aspects of this problem solution. Based on the obtained result, the optimal rehabilitation method was adopted that involves formation the neutral buffer zone of waste lime, filler, minimum height of $0.1 \mathrm{~m}$ above the endangered surface by flotation tailings and filling up the humus layer, height of $0.5 \mathrm{~m}$ above the limestone filler.
\end{abstract}

Keywords: rehabilitation, degraded areas, Electra method

\section{INTRODUCTION}

Due to frequent accidents in the seventies of the twentieth century, the flotation tailings from the mine Bor was directly discharged into the Bor River, where both of its banks were contaminated as well as the banks of the river Timok in total area estimated at more than 2000 ha. These areas after forty years and still have no capacity for self-regeneration of the plant world.

According to the causes of occurrence, the accidental situations on the flotation tailing dump Bor are classified into two main groups:
1. Due to technical deficiencies (inadequate designs, lack of control and non-compliance the regulations, power failures, failures in hydraulic and gravitational transport of flotation tailings, etc.), and

2. Due to the natural (atmospheric precipitation in the form of large water).

As the result, instead of discharging into predicted accumulation area of the Bor flotation tailing dump, the flotation tailings through the collector of sewage was directly discharged into the Bor River. When the

\footnotetext{
* University of Belgrade, Technical Faculty in Bor

** Mining and Metallurgy Institute Bor

**** This work in the results of the Project TR 34023 "Development the Technological Processes of Treatment the Non-standard Copper Concetrates to the Aim of Optimization the Emission of Polluting Materials and TR 37001 "The Effect of Mine Waste from RTB Bor and Pollutoion the Waterflows with a Proposal of Measures and Procedures for Reductid the Harmful Effect on the Environment", funded by the Ministry of Education, Science and Technological Development of the Republic of Serbia
} 
water level was low, due to the nature of lowland river, the flotation tailings was deposited along the riverbed. With the rise of the river water level, there was raising of tailings particles and creating a flood wave and application of flotation tailings on arable land in the valley of the Bor River.

Deposition the particles of flotation tailings from the flood wave to flooded soil was made depending on grain size, flow rate and height of flood wave. Sedimentation rate (extraction) of tailings particles from the water depended also on their diameter and density. Particles larger in diameter were deposited rapidly, while particles smaller in diameter remained long in the water of flood wave. According to the study, larger fractions were deposited along the river close to the accident site, while finer fractions were deposited away, and suspended particles were transported up to the mouth of the river Timok into the Danube and beyond.

Flotation tailings, obtained by flotation of copper ore, in its composition in addition to heavy metals also contained reagents (activators, deprimators and frothers) and thus represent a threat to the environment.

The solution to this problem can be achieved by selection and applying the appropriate methods of rehabilitation of degraded areas with flotation tailings disposal $[1,2,3,4]$. Rehabilitation (remediation) is the process of taking measures to stop pollution and further degradation of the environment to a level that is safe for future use of the site including landscaping, rehabilitation and reclamation of hazardous areas.

Today, there are a number of different repair methods that allow the revitalization of degraded areas to a greater or lesser extent, where the degraded surfaces can be transferred into a state that allows their use for various purposes. Modern approaches consider the selection of remediation methods as the process of multi-criteria decisionmaking with a finite number of considered alternatives (methods) to be assessed in relation to different and conflict criteria and conflict [5].
The advantage of multi-criteria decisionmaking is that it can simultaneously consider both financial and non-financial factors in the process of selection. The best known multi-criteria methods are models of assessment, analytic hierarchy process - AHP, analytic network process - ANP, TOPSIS, ELECTRE and PROMETHEE.

ELECTRE (Elimination and (Et) Choice Translating Reality) is one of multiple criteria decision making method for decisionmaking in the selection of the best solution among the alternatives, and the author of this method is Bernard Roy [6].

\section{PROPOSED METHODS \\ (ALTERNATIVE) FOR REHABILI- TATION OF DEGRADED AREAS}

The best available techniques are always based on official directives, in our case it is the Dorective on Landfills, which also includes the modern technology of remediation, researched and tested throughout the European Union [7, 8].

For rehabilitation of degraded land around the Bor River downstream from the village of Slatina, several alternatives are considered, namely:

Deep plowing (alternative A1) of areas covered with a layer of flotation tailings. Thus the flotation tailings reach into earth at depths up to $90 \mathrm{~cm}$ and a layer of soil from depth reaches the surface and covers the flotation tailings. This solution is one of the cheaper ways of rehabilitation under the condition of presence the powerful tractors. However, due to the period of 30-50 years of standing of tailings, there was a migration of heavy metals in soil and soil acidification to $\mathrm{pH} 3$, so the reclamation and biological measures should be applied each year (planting of plants that have the ability to take heavy metals from soil). Also, this method is not effective in those parts of degraded land where the layer of tailings is significantly higher than $90 \mathrm{~cm}$ (in some parts of the degraded soil a layer thickness of tailings goes up to $3 \mathrm{~m}$ ). 
Recycling (alternative A2) is the treatment of contaminated soil obtaining the useful components from deposits of flotation tailings where the solid and liquid waste is obtained. Solid waste in the form of tailings is transported to the flotation tailing dump where it is permanently disposed if there is free space. Liquid waste occurs in the form of chemical and mechanical contaminated water which must be purified before discharging into the watercourse.

Removal of deposits (alternative A3) of flotation tailings from threatened areas by bulldozers, loaders and trucks. By this method, the tailings are transported to a new location prepared for permanent storage of flotation tailings. Ameliorative measures should be applied on treated areas, which consist of the addition of calcite, lime, zeolite in order to regulate the $\mathrm{pH}$ value of the soil. The treated areas are then plowed and can be reused for growing crops. This procedure is very expensive.

Formation of a neutral buffer zone (alternative A4) of waste lime - filler of minimum height of $0.1 \mathrm{~m}$ between the threatened areas with flotation tailings and newly filled humus layer, height of $0.5 \mathrm{~m}$. In this way, neutralization is made or prevent, due to acid rain, decomposition the surface layer of tailings, to form the acid waste water, which have, in addition to low $\mathrm{pH}$ value, heavy metal ions, which are highly harmful, and which can, by means of water or food to get into the human body. This method involves flattening the surface and filling lime filler at minimum height of $0.1 \mathrm{~m}$ (buffer zone) and filling in the humus layer height of $0.5 \mathrm{~m}$. Transport of lime - filler would be from the site Zagradje, and transport of humus would be from the areas planned for expansion the Field 1 of the flotation tailing dump Veliki Krivelj before upgrading the Field 1. This is followed by humus planning with bulldozer and loosening of humus with cultivator (terminal tractor machine) for carrying out the biological reclamation. Supply of humus from the borrow pit includes excavation, loading, transport and planning (leveling) and loosening of humus on the intended area for rehabilitation.

\section{DEFINING THE CRITERIA FOR SELECTION THE OPTIMUM METHOD OF REHABILITATION THE DEGRADED AREAS}

The criteria include the most important factors for selection the appropriate method of rehabilitation the degraded land around the Bor River. These criteria are as follows:

Possibility of technical realization (Criterion C1) indicates the required technique and technology for implementation the adopted method of rehabilitation. Some of the proposed methods of rehabilitation require techniques and workforce, greater complexity of technology and vice versa. This criterion is very important and has a significant impact on selection the optimum method of rehabilitation. Therefore, its weight coefficient was determined (level of influence on decision making) which is 0.25 .

Costs (Criterion C2) are very important factor that often have a crucial impact on decision making. Costs are determined for each proposed method of rehabilitation and their impact is proportional to the obtained values. The weight coefficient of this criterion is 0.25 .

The obtained results (Criterion C3) are the expected quality of the resulting land after rehabilitation. The revitalized land depends on quality whether it can be used for planting various crops that will be used for human and animal feeding, or if this land will be sown with crops which will have a task to prevent erosion and absorb heavy metals from the soil. Due to its importance, its weight coefficient of 0.25 was determined.

Duration of rehabilitation (Criterion C4) is an important criterion that has a significant impact on decision making. Problem of rehabilitation requires faster response, and implementation one of the methods that will quickly be realized and to give the first results in a shorter period of time. The weight coefficient of this criterion is 0.10 . 
Universality of method (Criterion C5) indicates the possibility of using the certain method of rehabilitation in all conditions and on the overall area that is designated for rehabilitation. Nemaly, due to the terrain configuration, different flow rates of water in the Bor River and the size and intensity of flood waves, there have been various levels of soil contamination. For example, deposition of coarser particles was closer to the site of damage, while the finest particles were carried by the water nut and they were deposited furthest from the occurrence of accident and at the mouth of the Bor River into Timok. All this caused a big difference in thickness and surface of flotation tailings deposits. Taking all this into account, and in order to maintain more effective rehabilitation of degraded land, it is very important to choose one method of rehabilitation which will be applicable to the entire contaminated area. Because of its importance, its weight coefficient of 00:15 was determined.

\section{ELECTRE METHOD}

ELECTRE method, as a method for multi-criterion decision making is based on comparing the action in pairs. In this method, firstly the degree of agreement between the weight preferences and paired relationship of domination is determined, then the degree of disagreement on which the evaluation of weight of individual actions are mutually different. This method has among the first introduced the possibility of quantifying in the problems of qualitative decision making. For the solution of problem, it is necessary to first define the alternatives. After that, the criteria are defined that are important in decision making, or that have a decisive influence on decision making. Each criterion receives a certain weight, which is proportional to its importance, and the sum of all weights must be equal to 1. ELECTRE method is based on the decision matrix and the weight criteria and the problem is solved in nine steps, i.e. establishing the best alternative. Steps in solving are:

1. Calculation of normalized decision matrix.
2. Calculation of weighted normalized decision matrix.

3. Determination of sets of agreement and disagreement.

4. Calculation of agreement matrix.

5. Calculation of disagreement matrix.

6. Calculation of domination matrix by agreement.

7. Calculation of domination matrix by disagreement.

8. Calculation of aggregate matrix of domination.

9. Elimination the weakest alternative.

In the process of elimination the value of less desirable actions, it is necessary to examine the state of domination for all possible combinations of pairs of actions. Action with a larger number of elements $(\operatorname{mad}=1)$, dominates over the others, and in a situation when the number of such elements it is not possible to determine the state of domination. The same conclusion about the absence of domination between individual actions can be performed in the case of actions where all elements are mad $=0$. As the situation of impossibility of defining the state of domination applying the method of ELECTRE are frequent, due to this, the method belongs to a group of methods for determining the sequence of partial preferences.

\section{RESULTS OF SELECTION THE OPTIMUM METHOD OF REHABI- LITATION THE DEGRADED AREAS}

Based on defined criteria, the evaluation of all proposed methods of rehabilitation the degraded areas is carried out and an evaluation matrix is formed. In this process, all criteria have qualitative or uncertain structure that cannot be precisely determined and measured. Accordingly, a qualitative scale is formed with five levels. Table 1 presents a qualitative scale, as well as the correspondding numerical values for each qualitative evaluation.

Using the qualitative scale from 1 to 5 , the quantified decision matrix is obtained (Table 2). 
Table 1 Qualitative scale

\begin{tabular}{|l|c|c|c|c|c|}
\hline Qualitative values & Very bad & Bad & Medium & High & Very high \\
\hline Numerical values & 1 & 2 & 3 & 4 & 5 \\
\hline
\end{tabular}

Table 2 Quantified decision matrix

\begin{tabular}{|c|c|c|c|c|c|}
\hline Alternatives/Criteria & C1 & C2 & C3 & C4 & C5 \\
\hline $\mathbf{A 1}$ & 5 & 5 & 2 & 4 & 1 \\
\hline $\mathbf{A 2}$ & 3 & 4 & 3 & 3 & 5 \\
\hline $\mathbf{A 3}$ & 1 & 1 & 5 & 1 & 5 \\
\hline $\mathbf{A 4}$ & 4 & 3 & 5 & 3 & 5 \\
\hline
\end{tabular}

Based on quantified decision matrix, calculation is performed by ELECTRE method. In this, the software ELECTRE is used. The steps of calculation are as follows:

\section{Step I:}

Calculation of normalized decision matrix. Calculation formula is as follows:

$$
\mathrm{n}_{\mathrm{ij}}=\frac{\mathrm{c}_{\mathrm{ij}}}{\text { Norma }_{\mathrm{j}}}=\frac{\mathrm{c}_{\mathrm{ij}}}{\sqrt{\sum_{\mathrm{i}=1}^{\mathrm{m}} \mathrm{c}_{\mathrm{ij}}^{2}}}
$$

Based on data for this example, the following normalized decision matrix is obtained (Table 3):

Table 3 Normalized decision matrix

\begin{tabular}{|c|c|c|c|c|c|}
\hline Alternatives/Criteria & C1 & C2 & C3 & C4 & C5 \\
\hline A1 & 0.70014 & 0.70014 & 0.25198 & 0.67612 & 0.11471 \\
\hline $\mathbf{A 2}$ & 0.42008 & 0.56011 & 0.37796 & 0.50709 & 0.57354 \\
\hline $\mathbf{A 3}$ & 0.14003 & 0.14003 & 0.62994 & 0.16903 & 0.57354 \\
\hline A4 & 0.56011 & 0.42008 & 0.62994 & 0.50709 & 0.57354 \\
\hline
\end{tabular}

\section{Step II:}

Calculation of weight normalized decision matrix.

In this step, the decision maker must demonstrate its preferences for attributes on which selects one of four possible methods of rehabilitation. Then, the weight normalized decision matrix is calculated. Matrix of elected weight coefficients is as follows:

$$
T N=N \cdot T
$$

where

$$
T=\left[\begin{array}{cccc}
t_{1} & \cdots & \cdots & 0 \\
\cdots & t_{2} & \cdots & \cdots \\
\cdots & \cdots & \cdots & \cdots \\
0 & \cdots & \cdots & t_{n}
\end{array}\right]
$$

and $\mathrm{N}$ is the normalized decision matrix.

The sum of diagonal matrix elements of assigned weights to individual attributes (T) must be equal to one, i.e.

$$
\sum_{j=1}^{m} t_{j}=1
$$

Multiplying the normalized matrix and the matrix of selected weight coefficients, the weight normalized decision matrix is obtained (Table 4): 
Table 4 Weight normalized decision matrix

\begin{tabular}{|c|c|c|c|c|c|}
\hline Alternatives/Criteria & C1 & C2 & C3 & C4 & C5 \\
\hline $\mathbf{A 1}$ & 0.17503 & 0.17503 & 0.06299 & 0.06761 & 0.01721 \\
\hline $\mathbf{A 2}$ & 0.10502 & 0.14003 & 0.09449 & 0.05071 & 0.08603 \\
\hline $\mathbf{A 3}$ & 0.03501 & 0.03501 & 0.15749 & 0.01690 & 0.08603 \\
\hline $\mathbf{A 4}$ & 0.14003 & 0.10502 & 0.15749 & 0.05071 & 0.08603 \\
\hline
\end{tabular}

\section{Step III:}

Determination the sets of agreement (S) and disagreement (NS).

In this step, the pairs of actions are compared. Actions that are compared are marked with $\mathrm{p}$ and $\mathrm{r}(\mathrm{p}, \mathrm{r}=1,2, \ldots, \mathrm{m}$ and $\mathrm{p} \neq \mathrm{r}$ ). First, a set of agreement (Spr) is formed for actions $a_{p}$ and $a_{r}$ which consists of all criteria $(\mathrm{J}=\mathrm{j}$ and $\mathrm{j}=1,2, \ldots, \mathrm{n})$, for which the action $\mathrm{a}_{\mathrm{p}}$ is more preferable than action $a_{r}$, i.e.

$$
S_{p r}=\left(j \mid x_{p j} \geq x_{r j}\right)
$$

If there is a criterion of minimum type, the sign of inequality is opposite $(\leq)$. Then, a complementary set of disagreement is formed, for which the following is applied:

$$
N S_{p r}=\left(j \mid x_{p j} \prec x_{r j}\right)=J-S_{p r}
$$

If there is a criterion of minimum type, the sign of inequality is opposite (>).

\section{Step IV:}

Determination the matrix of agreement (MS)

Matrix of agreement is calculated based on the sets of agreement, calculated in the previous step. The elements of this matrix include the indexes of agreement. Their value is calculated as the sum of preferences (weight coefficients), which correspond to the corresponding elements of the sets of agreement. Index of agreement $S_{p r}$ for actions $\mathrm{a}_{\mathrm{p}}$ and $\mathrm{a}_{\mathrm{r}}$ is calculated as:

$$
M S_{p r}=\sum_{j \in S_{p r}} t_{j}
$$

Value $S_{p r}$ is in the interval from 0 to 1 . As the value of this index is closer to one, the action $\mathrm{a}_{\mathrm{p}}$ is more preferable than action $\mathrm{a}_{\mathrm{r}}$ (according to the criteria of agreement). Indexes of agreement form the matrix of agreement, which has the elements equal to zero on the main diagonal, because it does not perform comparison of alternative with itself. Matrix of agreement for this example is as follows (Table 5):

Table 5 Matrix of agreement

\begin{tabular}{|c|c|c|c|c|}
\hline Alternative A1 & 0 & 0.60000 & 0.60000 & 0.60000 \\
\hline Alternative A2 & 0.40000 & 0 & 0.75000 & 0.50000 \\
\hline Alternative A3 & 0.40000 & 0.40000 & 0 & 0.40000 \\
\hline Alternative A4 & 0.40000 & 0.75000 & 1.0000 & 0 \\
\hline
\end{tabular}

\section{Step V:}

Determining the matrix of disagreement (MNS).

The elements of matrix of disagreement consist of disagreement indexes, which are calculated as follows, using the matrix TN (weight normalized matrix):

$$
M N S_{p r}=\frac{\max _{j \in N S_{p r}}\left|t_{p j}-t_{r j}\right|}{\max \left|t_{p j}-t_{r j}\right|}
$$

Index of disagreement is in the interval from 0 to 1 , and shows how much the alternative $a_{p}$ is less desirable than the alterna 
tives $\mathrm{a}_{\mathrm{r}}$. As the disagreement index is higher (closer to one) it is, according to the criterion of disagreement, the alternative $a_{p}$ is less desirable than the alternative $\mathrm{a}_{\mathrm{r}}$. Disagreement indexes are calculated on the basis of weight normalized decision matrix (TN) and a set of disagreement for the observed alternatives $\left(\mathrm{NS}_{\mathrm{pr}}\right)$.

Matrix of disagreement is shown in Table 6 .

Table 6 Matrix of disagreement

\begin{tabular}{|c|c|c|c|c|}
\hline $\begin{array}{c}\text { Alternative } \\
\text { A1 }\end{array}$ & 0 & 0.98300 & 0.67490 & 1.00000 \\
\hline Alternative A2 & 1.00000 & 0 & 0.59989 & 1.00000 \\
\hline Alternative A3 & 1.00000 & 1.00000 & 0 & 1.00000 \\
\hline Alternative A4 & 0.74085 & 0.55571 & 0.00000 & 0 \\
\hline
\end{tabular}

\section{Step VI:}

Determination of the matrix of agreement domination (MSD).

The elements of this matrix are calculated based on a threshold value of the agreement index. A threshold of index is defined as the average index of agreement, which is calculated by the following formula:

$$
P I S=\sum_{\substack{p=1 \\ p \neq r}}^{m} \sum_{\substack{r=1 \\ p \neq r}}^{m} \frac{M S_{p r}}{m(m-1)}
$$

Based on the obtained value of the average index of agreement, it can be said that the action $a_{p}$ is likely to be preferable than the action $a_{r}$, only if its corresponding index of agreement $\mathrm{MS}_{\mathrm{pr}}$ exceeds the value of the average index of agreement. Matrix of agreement domination is based on the following criteria:

$$
\begin{array}{lll}
M S D_{p r}=1 & \text { for } & M S_{p r} \geq P I S \\
M S D_{p r}=0 & \text { for } & M S_{p r} \prec P I S
\end{array}
$$

Matrix of agreement domination is given in Table 7.

Table 7 Matrix of agreement domination

\begin{tabular}{|l|l|l|l|l|}
\hline Alternative A1 & 0 & 1 & 1 & 1 \\
\hline Alternative A2 & 0 & 0 & 1 & 0 \\
\hline Alternative A3 & 0 & 0 & 0 & 0 \\
\hline Alternative A4 & 0 & 1 & 1 & 0 \\
\hline
\end{tabular}

\section{Step VII:}

Determining the matrix of disagreement domination.

Similar to the previous step, the matrix of disagreement domination is calculated such as the average index of disagreement is calculated firstly over the relation:

$$
\text { PINS }=\sum_{\substack{p=1 \\ p \neq r=1 \\ p \neq r}}^{m} \frac{M N S_{p r}}{m(m-1)}
$$

Matrix of disagreement domination is given in Table 8. 
Table 8 Matrix of disagreement domination

\begin{tabular}{|l|l|l|l|l|}
\hline Alternative A1 & 0 & 0 & 1 & 0 \\
\hline Alternative A2 & 0 & 0 & 1 & 0 \\
\hline Alternative A3 & 0 & 0 & 0 & 0 \\
\hline Alternative A4 & 1 & 1 & 1 & 0 \\
\hline
\end{tabular}

\section{Step VIII:}

Determining the matrix of aggregate domination (MAD).

This matrix is obtained as the product of positions the elements of the agreement and disagreement matrix (it is not a classical

matrix calculation) as follows:

$$
M A D_{p r}=M S D_{p r} \cdot M N S D_{p r}
$$

Matrix of aggregate domination is as follows (Table 9):

Table 9 Matrix of aggregate domination

\begin{tabular}{|c|c|c|c|}
\hline A1 & 0 & 1 & 0 \\
\hline 0 & A2 & 1 & 0 \\
\hline 0 & 0 & A3 & 0 \\
\hline 1 & 1 & 1 & A4 \\
\hline
\end{tabular}

\section{Step IX:}

Eliminating the less desirable actions.

If the value $\mathrm{MAD}_{\mathrm{pr}}=1$, then the action $\mathrm{a}_{\mathrm{p}}$ dominates over the action $\mathrm{a}_{\mathrm{r}}$, by both criterion (agreement and disagreement). But that does not mean that there is no other alternative that does not dominate over $a_{p}$. Therefore, it is necessary satisfy another one condition:

$\mathrm{MAD}_{\mathrm{pr}}=1$ for at least one $\mathrm{r}, \mathrm{r}=1,2, \ldots$, $\mathrm{m}$ and $\mathrm{p} \neq \mathrm{r}$

$\mathrm{MAD}_{\mathrm{pr}}=0$ for all i, i $=1,2, \ldots, \mathrm{m}$ and $\mathrm{p} \neq \mathrm{r}$ i i $\neq \mathrm{r}$

The obtained results of realized multicriteria analysis suggest the following:

- A1 dominates over: A3

- A2 dominates over: A3

- A3 does not dominate over any action

- A4 dominates over: A2 A3

- The best alternative: A4.

The results show that the alternative A4 is the best (formation the neutral buffer zone), followed by alternative A1 (deep plowing) and A2 (recycling), and, finally, the alternative A3 (removal of deposits).

\section{ANALYSIS OF THE OBTAINED DATA}

The optimum alternative A4, or the method of rehabilitation that involves the formation of a neutral buffer zone over the sediments of flotation tailings of lime and filling of humus over the buffer zone has the highest ratings in relation to other aspects of the criterion C3 (obtained - the expected results) and C5 (universal of method). Also, this method is in the second place regarding to the criteria $\mathrm{C} 1$ (possibility of technical realization of rehabilitation), and in the middle compared to other methods as far as the criterion C2 (costs of rehabilitation) and C4 (duration of rehabilitation). It shows that this method, after its implementation, provide the uninterrupted use of the rehabilitated land for cultivation of various crops that can be used for human and animal feeding, then 
it can be used for complete rehabilitation of degraded areas, regardless of their degree of degradation; technically not complicated to perform, and the costs and time required for its realization are moderate compared to the other proposed methods of rehabilitation.

Alternative A1 (deep plowing the deposits of flotation tailings) is ranked in the second place. It has the highest ratings as regards the criteria $\mathrm{C} 1$ and $\mathrm{C} 2$, and $\mathrm{C} 4$ regarding to the other methods, but it has the lowest ratings in terms of criteria $\mathrm{C} 3$ and $\mathrm{C} 5$. This indicates that it is the easiest to implement, the least expensive and requires the shortest time of implementation. On the other hand, this method gives the lowest expected results because the remediated land cannot be used for growing crops for human and animal feeding due to the mixing of flotation tailings deposits with humus and is not applicable at all degraded areas, especially where the flotation tailings deposit is thicker than $90 \mathrm{~cm}$.

Alternative A2 (recycling the flotation tailings deposits) is ranked in the third place. It has the highest ratings regarding the criterion $\mathrm{C} 5$, the second place regarding the criterion $\mathrm{C} 2$, and in the middle from an aspect of other three criteria $(\mathrm{C} 1$, $\mathrm{C} 3$ and $\mathrm{C} 4)$. It shows that this method can be effectively used at all degraded areas, it is moderate in terms of the costs and time of implementation, medium complicated to implement and gives good results.

Finally, the alternative A3 (removal the flotation tailings sediments from contaminated land) is ranked in the last fourth place. It has the highest ratings regarding the criteria $\mathrm{C} 3$ and $\mathrm{C} 5$, and the lowest ratings in comparison with the criteria $\mathrm{C} 1, \mathrm{C} 2$ and $\mathrm{C} 4$. It shows that this method provides a complete rehabilitation of degraded land and high expected results, and that it can be used for rehabilitation of entire degraded area. On the other hand, this method is technically the most difficult for implementation (requires complex and expensive equipment and technology), it is the most expensive and re quires a longer time for implementation in relation to other methods of rehabilitation.

\section{CONCLUSION}

This work presents the applied multicriteria decision-making method in order to select the optimum method of rehabilitation the degraded areas of the Bor River coast. Selection of optimum methods of rehabilitation the degraded areas of the Bor River coast is one of the most important decisions in the course of project management for revitalization the destroyed and contaminated surfaces created by long year mining in this area. At the same time, four possible methods of rehabilitation were considered - deep plowing of areas covered with a layer of flotation tailings (alternative A1), recycling the flotation tailings deposits (alternative A2), removal of flotation tailings deposits from contaminated land (alternative A3) and formation the neutral buffer zone over the flotation tailings deposits of lime and filling of humus over the buffer zone (alternative $\mathrm{A} 4$ ). The selection process requires consideration of a number of criteria such as the possibility of technical implementation of rehabilitation process (Criterion $\mathrm{C} 1$ ), the costs of rehabilitation (Criterion $\mathrm{C} 2$ ), the expected results of rehabilitation (Criterion C3), duration of rehabilitation (Criterion C4), and universality of the applied method of rehabilitation (Criterion C5). Selection the optimum method of rehabilitation is performed on the basis of comparison the applicable methods in accordance with the relevant criteria.

Accordingly, the ELECTRE method of decision-making is used in this work. In this approach, determining the weight coefficients of criteria for selection the optimum method of rehabilitation is firstly carried out, and then evaluating the proposed methods and their complete ranking.

The proposed method for decision making can be of great help to the deci- 
sion makers because it allows easy analysis of influential factors and parameters. Accordingly, on the basis of the results obtained by ELECTRE, the best method of rehabilitation was selected, and it is formation the neutral buffer zone over the flotation tailings deposits of lime and filling of humus over the buffer zone (alternative A4). The most influential criteria for a complete ranking of alternatives (rehabilitation method) are the possibility of technical realization (Criterion C1), costs (Criterion C2) and obtained (expected) results (Criterion C3).

\section{REFERENCES}

[1] Komnitsas K., Baptzas G., Paspaliaris I., Clean up of Acidic Leachate Using Fly Ash Barriers: Laboratory Column Studies, Proc. 8th Int. Conf. on Environmental Science and Technology, Lemnos Island (2003);

[2] Komnitsas K., Lazar I., Petrisor I., Application of a Vegetative Cover on Phosphogypsum Stacks, Minerals Engineering, 12 (1999), 175-185;

[3] Komnitsas K., Xenidis A., Tabouris S., Composite Cover for the Prevention Of Acid Mine Drainage, Mining Enviromental Management, 8 (2000), 14-17;
[4] Peppass A., Komnitsas K., Halikia I., Use of Organic Covers for Acid Mine Drainage Control, Minerals Engineering, 13 (2000), 563-574;

[5] Bufardi A., Gheorghe R., Kiritsis D.and Hirouchakis P., Multicriteria Decision-aid Approach for Product End-of-life Alternative Selection, International Journal of Production Research, 42 (2004), 3139-3157;

[6] Roy B., The Outranking Approach and the Foundation of Electre Methods, Theory Decision 31 (1991), 49-73;

[7] Council Directive, (1999), Directive 1999/31/EC of the European Parliament and of the Council of 26 April 1999 on the Landfill of Waste, Official Journal of the European Communities, OJ L 182, 16.07.1999, Brussels;

[8] EC Directive (2008), Directive 2008/98/EC of the European Parliament and of the Council of 19 November 2008, on Waste and Repealing Certain Directives, Official Journal of the European Communities, L312/3, 22.11.2008, Brussels. 


\begin{tabular}{ll}
\hline \hline INSTITUT ZA RUDARSTVO I METALURGIJU BOR & ISSN: 2334-8836 (Štampano izdanje) \\
UDK: 622 & ISSN: 2406-1395 (Online) \\
\hline \hline
\end{tabular}

\author{
Dejan Bogdanović, Ljubiša Obradovic ${ }^{* *}$, Slavica Miletic ${ }^{* *}$ \\ IZBOR OPTIMALNE METODE SANACIJE
DEGRADIRANIH POVRŠINA OKO BORSKE REKE
NIZVODNO OD FLOTACIJSKOG JALOVIŠTA BOR
}

Izvod

Problem zagađenosti voda i zemljišta u priobalju Borske reke nizvodno od Flotacijskog jalovišta Bor datira još iz sedamdesetih godina prošlog veka. U radu je izvršen izbor optimalne metode sanacije degradiranih površina obale Borske reke. Razmatrane su četiri moguće metode za sanaciju degradiranih površina, a izbor najbolje je izvršen pomoću multikriterijumske analize. Pri tome, korišćena je Electre metoda koja je omogućila izbor otimalne metode sanacije uzimajući u obzir pet kriterijuma koji pokrivaju najvažnije aspekte rešenja ovog problema. Na osnovu dobijenog rezultata, kao optimalna metoda sanacije usvojena je metoda koja podrazumeva formiranje neutralne tampon zone od otpadnog kreča filera minimalne visine $0,1 \mathrm{~m}$ iznad ugrožene površine flotacijskom jalovinom i nasipanja humusne zemlje u sloju visine 0,5 m iznad kreča filera.

Ključne reči: sanacija, degradirane površine, Electre metoda

\title{
1. UVOD
}

Usled čestih akcidentnih situacija sedamdesetih godina dvadesetog veka flotacijska jalovina iz Borskog rudnika je ispuštana direktno u Borsku reku, pri čemu su zagađene obe njene obale, kao i obale reke Timok u ukupnoj površini koja je procenjena na više od 2000 ha. Ove površine $i$ posle četrdeset $i$ više godina i dalje su bez sposobnosti za samoobnavljanje biljnog sveta.

Prema uzrocima nastajanja, akcidentne situacije na flotacijskom jalovištu Bor su svrstane u dve osnovne grupe:
1. Usled tehničkih nedostataka (neadekvatnih projektnih rešenja, odsustva kontrole i nepoštovanja propisa, nestanak struje, kvarovi na hidrauličnom i gravitacionom transportu flotacijske jalovine i dr.), i

2. Usled prirodnih nepogoda (atmosferskih padavina u vidu velikih voda).

Usled toga, umesto ispuštanja u predviđeni akumulacioni prostor flotacijskog jalovišta Bor, flotacijska jalovina je preko kolektora za fekalne vode ispuštana direktno

\footnotetext{
*Univerzitet u Beogradu-Tehnički Fakultet u Boru

** Institut za rudarstvo i metalurgiju Bor

*** Ovaj rad je proistekao kao rezultat projekta TR 34023 "Razvoj tehnoloških procesa prerade nestandardnih koncentrata bakra u cilju optimizacije emisije zagađujućih materijala" i TR37001 „Uticaj rudarskog otpada iz RTB Bor na zagađenje vodotokova, sa predlogom mera i postupaka za smanjenje štetnog dejstva na životnu sredinu “finansiranih od strane Ministarstva prosvete, nauke $i$ tehnološkog razvoja Republike Srbije
} 
u Borsku reku. Kada je vodostaj reke bio nizak, zbog karaktera ravničarske reke, flotacijska jalovina se taložila duž korita reke. Sa porastom vodostaja reke dolazilo je do podizanja čestica jalovine i stvaranja poplavnog talasa i nanošenja flotacijske jalovine na plodne njive $\mathrm{u}$ dolini Borske reke.

Taloženje čestica flotacijske jalovine iz poplavnog talasa na poplavljeno tlo vršilo se u zavisnosti od veličine zrna, brzine protoka i visine poplavnog talasa. Brzina sedimentacije (izdvajanja) čestica jalovine iz vode zavisila je i od njihovog prečnika i gustine. Čestice većeg prečnika taložile su se brže, dok su čestice manjeg prečnika ostajale dugo u vodi poplavnog talasa. Prema istraživanju, krupnije frakcije su se taložile uz tok reke bliže mestu udesa, dok su se sitnije frakcije sedimentovale dalje, a lebdeće ćestice transportovane su čak do ušča reke Timok u Dunav i dalje.

Flotacijska jalovina dobijena flotiranjem rude bakra u svom sastavu pored teških metala sadržala je reagense (aktivatore, deprimatore i penušače) pa time predstavlja opasnost po životnu sredinu.

Rešenje ovog problema se može postići izborom i primenom odgovarajuće metode sanacije degradiranih površina flotacijskom jalovinom [1, 2, 3, 4]. Sanacija (remedyjacija) je proces preduzimanja mera za zaustavljanje zagađenja i dalje degradacije životne sredine do nivoa koji je bezbedan za buduće korišćenje lokacije uključujući uređenje, revitalizaciju i rekultivaciju ugroženog prostora.

Danas su na raspolaganju veći broj različitih metoda sanacije koje omogućavaju revitalizaciju degradiranih površina u većem ili manjem obimu, pri čemu se degradirane površine mogu prevesti u stanje koje omogućavaju njihovo korišćenje u razne svrhe. Moderni pristupi razmatraju selekciju metode sanacije kao proces višekriterijumskog odlučivanja sa konačnim brojem razmatranih alternativa (metoda) koje se ocenjuju $u$ odnosu na više različitih $i$ konfliktih kriterijuma [5].
Prednost višekriterijumskog odlučivanja je $\mathrm{u}$ tome što on može istovremeno da razmatra i finansijske i nefinansijske faktore pri postupku izbora. Najpoznatije višekriterijumske metode su modeli ocenjivanja, analitički hijerarhijski proces - AHP, analitičke mreže procesa - ANP, TOPSIS, ELECTRE i PROMETHEE.

ELECTRE (Eliminationand (Et) Choice Translating Reality) je jedna od metoda višekriterijskog odlučivanja za donošenja odluka u izboru najpovoljnijeg rešenja među alternativama, a autor ove metode je Bernard Roy [6].

\section{PREDLOŽENE METODE \\ (ALTERNATIVE) SANACIJE DEGRADIRANIH POVRŠINA}

Najbolje dostupne tehnike su uvek bazirane na zvaničnim direktivama, u našem slučaju to je direktiva o deponijama, koja takođe obuhvata i savremene tehnike i tehnologije rekultivacije, istraživane i proverene širom Evropske Unije [7, 8].

Za sanaciju degradiranog zemljišta oko Borske reke nizvodno od sela Slatina razmatraju se više alternativa i to:

Duboko zaoravanje (alternativa A1) površina prekrivenih slojem flotacijske jalovine. Flotacijska jalovina na taj način dospeva u zemlji dubine i do $90 \mathrm{~cm}$, a sloj zemlje sa dubine dospeva na površinu $\mathrm{i}$ prekriva flotacijsku jalovinu. Ovo rešenje spada u jeftinije načine sanacije pod uslovom da se imaju moćni traktori. Međutim, usled perioda od 30-50 godina stajanja flotacijske jalovine došlo je do migracije teških metala u zemljište i zakišeljavanja zemljišta do $\mathrm{pH} 3$, pa bi svake godine trebalo da se primene meliorativne i biološke mere (sejanje biljaka koje imaju sposobnost uzimanja teških metala iz zemljišta). Takođe, ova metoda nije delotvorna u onim delovima degradiranog zemljišta gde je sloj jalovine znatno veći od $90 \mathrm{~cm}$ (u nekim delovima degradiranog zemljišta debljina sloja flotacijske jalovine ide i do $3 \mathrm{~m}$ ). 
Reciklaža (alternativa A2) predstavlja prečišćavanje kontaminiranog zemljišta dobijanjem korisnih komponenata iz nanosa flotacijske jalovine, pri čemu se dobija čvrst i tečni otpad. Čvrst otpad u vidu jalovine se vozi na flotacijsko jalovište gde se trajno odlaže ako postoji slobodan prostor. Tečni otpad se pojavljuje u vidu hemijski i mehaničkih zaprljanih voda koje moraju da se prečiste pre ispuštanja u vodotok.

Uklanjanje nanosa (alternativa A3) flotacijske jalovine sa ugroženih površina pomoću buldozera, utovarivača i kamiona. Ovom metodom se jalovina odvozi na novu lokaciju pripremljenu za trajno skladiranje flotacijske jalovine. Na očišćenim površinama treba primeniti meliorativne mere koje se sastoje od dodavanja kalcita, kreča, zeolita radi regulisanja $\mathrm{pH}$ vrednosti zem1jišta. Tretirane površine se zatim preoravaju i mogu se ponovo koristiti za gajenje useva. Ovaj postupak je veoma skup.

Formiranje neutralne tampon zone (alternativa A4) od otpadnog kreča - filera minimalne visine $0,1 \mathrm{~m}$ između ugroženih površina flotacijskom jalovinom i novo nasute humusne zemlje u sloju visine $0,5 \mathrm{~m}$. $\mathrm{Na}$ taj način se vrši neutralisanje, odnosno onemogućava se, usled kiselih kiša, razlaganje površinskog sloja jalovine, pri čemu se formiraju kisele otpadne vode, koje osim niske $\mathrm{pH}$ vrednosti u sebi obično nose $\mathrm{i}$ jone teških metala, koji su vrlo štetni i koji mogu putem vode ili hrane da dospeju u ljudski organizam. Ova metoda obuhvata ravnanje površina i nasipavanje kreča filera u sloju minimalne visine $0,1 \mathrm{~m}$ (tampon zone) $\mathrm{i}$ nasipavanje humusne zemlje u sloju visine $0,5 \mathrm{~m}$. Dovoz kreča - filera bi bio iz pogona Zagrađe, a dovoz humusne zemlje sa površna planiranih za proširenje Polja 1 flotacijskog jalovišta Veliki Krivelj pre nadogradnje Polja 1. Nakon toga sledi planiranje humusne zemlje buldozerom i rastresanje humusne zemlje setvospremačem (priključna mašina traktora) radi izvođenja biološke rekultivacije. Obezbeđenje humusne zemlje sa pozajmišta podrazumeva otkopavanje, utovar, transport i planiranje (nivelisanje) i rastresanje humusa na predviđenoj površini za sanaciju•

\section{DEFINISANJE KRITERIJUMA ZA IZBOR OTIMALNE METODE SANACIJE DEGRADIRANIH POVRŠINA}

Kriterijumi obuhvataju najvažnije faktore za izbor odgovarajuće metode sanacije degradiranog zemljišta oko Borske reke. Ti kriterijumi su sledeći:

Mogućnost tehničke realizacije (kriterijum C1) ukazuje na potrebnu tehniku i tehnologiju za realizaciju usvojene metode sanacije. Pojedine predložene metode sanacije zahtevaju veće angažovanje tehnike i radne snage, veću složenost tehnologije i obrnuto. Ovaj kriterijum je veoma važan i on ima značajan uticaj na izbor optimalne metode sanacije. Zbog toga, određen je njegov težinski koeficijent (nivo uticaja na donošenje odluke) koji iznosi 0.25 .

Troškovi (kriterijum C2) su vrlo važan faktor koji često presudno utiču na donošenje odluke. Troškovi se određuju za svaku predloženu metodu sanacije i njihov uticaj je srazmeran dobijenim vrednostima. Težinski koeficijent ovog kriterijuma iznosi 0.25.

Dobijeni rezultati (kriterijum C3) predstavlja očekivani kvalitet dobijenog zemljišta nakon sanacije. Od kvaliteta zavisi da li će revitalizovano zemljište moći da se koristi za sejanje raznih kultura koje će moći da se koriste za ishranu ljudi i životinja, ili će to zemljište biti zasejano kulturama koje će imati zadatak da spreče eroziju i da apsorbuju teške metale iz zemljišta. Zbog njegovog značaja određen mu je težinski koeficijent od 0.25 .

Trajanje sanacije (kriterijum C4) je važan kriterijum koji ima značajan uticaj na donošenje odluke. Problem sanacije zahteva brže reagovanje i primenu one metode koja će brže da se realizuje i u kraćem vremenskom periodu daje prve rezultate. Težinski koeficijent ovog kriterijuma je 0.10 . 
Univerzalnost metode (kriterijum C5) ukazuje na mogućnost primene određene metode sanacije u svim uslovima i na celokupnoj površini koja je predviđena za sanaciju. Naime, zbog konfiguracije terena, različite brzine protoka vode $\mathrm{u}$ Borskoj reci i veličine i intenziteta poplavnog talasa došlo je do različitih nivoa zagađenosti zemljišta. Na primer, sedimentovanje krupnijih čestica bilo je bliže mestu havarije, dok su najsitnije čestice nošene maticom $i$ one su se taložile najdalje od nastanka udesa $i$ to na ušću Borske reke u Timok. Sve je to uslovilo velike razlike u debljini i površini nanosa flotacijske jalovine. Uzimajući sve ovo u obzir, a u cilju što efikasnije sanacije degradiranog zemljišta, vrlo je važno da se izabere ona metoda sanacije koja će biti primenljiva na celokupnoj zagađenoj površini. Zbog njegovog značaja određen mu je težinski koeficijent od 0.15 .

\section{METODA ELECTRE}

Metoda ELECTRE, kao metoda višekriterijumskog odlučivanja počiva na upoređenju akcija u parovima. Kod ove metode se najpre određuje stepen saglasnosti između težina preferencija i uparenih veza dominacije, a potom stepen nesaglasnosti po kome se ocena težina pojedinih akcija međusobno razlikuje. Ova metoda je među prvima uvela mogućnost kvantifikacije kod problema kvalitativnog odlučivanja. Za rešenje problema potrebno je prvo definisati alternative. Nakon toga se definišu kriterijumi koji su važni kod donošenja odluke, odnosno koji imaju presudan uticaj na donošenje odlike. Svaki kriterijum dobija određene težine, koji je srazmeran njegovom značaju, a zbir svih težina mora biti jednak 1. Metoda ELECTRE polazi od matrice odlučivanja i težina kriterijuma i u devet koraka dolazi do rešenja problem, odnosno do određivanja najbolje alternative. Koraci u rešavanju su:

1. Računanje normalizovane matrice odlučivanja.
2. Računanje ponderisane normalizovane matrice odlučivanja.

3. Određivanje skupova saglasnosti i nesaglasnosti.

4. Računanje matrice saglasnosti.

5. Računanje matrice nesaglasnosti.

6. Računanje matrice dominacije po saglasnosti.

7. Računanje matrice dominacije po nesaglasnosti.

8. Računanje agregatne matrice dominacije.

9. Eliminisanje najslabijih alternative.

Kod postupka eliminisanja vrednosti manje poželjnih akcija potrebno je ispitati stanje dominacije za sve moguće kombinacije parova akcija. Akcija sa većim brojem elemenata (mad=1), dominira nad ostalim, a u situaciji kada je broj takvih elemenata isti nije moguće ustanoviti stanja dominacije. Isti zaključak o nepostojanju dominacije između pojedinih akcija se može izvesti i u slučaju akcija gde su svi elementi mad $=0$. Kako su situacije nemogućnosti definisanja stanja dominacije primenom metode ELECTRE česte, sama metoda zbog toga spada u grupu metoda za određivanje redosleda parcijalnih preferencija.

\section{REZULTATI IZBORA OPTIMALNE METODE SANACIJE DEGRADIRANIH POVRŠINA}

Na osnovu definisanih kriterijuma vrši se ocena svih predloženih metoda sanacije degradiranih površina $\mathrm{i}$ formira se matrica evaluacije. U ovom procesu svi kriterijumi imaju kvalitativnu ili neizvesnu strukturu koja se ne može precizno odrediti i izmeriti. Shodno tome, formira se kvalitativna skala koja ima pet nivoa. U tabeli 1 . data je navedena kvalitativna skala, kao i odgovarajuće numeričke vrednosti za svaku kvalitativnu ocenu.

Koristeći kvalitativnu skalu u rasponu od 1 do 5, dobija se kvantifikovana matrica odlučivanja (tabela 2.). 
Tabela 1. Kvalitativna skala

\begin{tabular}{|l|c|c|c|c|c|}
\hline Kvalitativne vrednosti & Vrlo slabo & Slabo & Srednje & Visoko & Vrlo visoko \\
\hline Numeričke vrednosti & 1 & 2 & 3 & 4 & 5 \\
\hline
\end{tabular}

Tabela 2. Kvantifikovana matrica odlučivanja

\begin{tabular}{|c|c|c|c|c|c|}
\hline Alternative/Kriterijumi & C1 & C2 & C3 & C4 & C5 \\
\hline A1 & 5 & 5 & 2 & 4 & 1 \\
\hline A2 & 3 & 4 & 3 & 3 & 5 \\
\hline A3 & 1 & 1 & 5 & 1 & 5 \\
\hline A4 & 4 & 3 & 5 & 3 & 5 \\
\hline
\end{tabular}

$\mathrm{Na}$ osnovu kvantifikovane matrice odlučivanja vrši se proračun ELECTRE metodom. Pri tome je korišćen softver ELECTRE. Koraci u proračunu su sledeći:

\section{I korak:}

Izračunavanje normalizovane matrice odlučivanja. Formula za izračunavanje je sledeća:

$$
\mathrm{n}_{\mathrm{ij}}=\frac{\mathrm{c}_{\mathrm{ij}}}{\text { Norma }_{\mathrm{j}}}=\frac{\mathrm{c}_{\mathrm{ij}}}{\sqrt{\sum_{\mathrm{i}=1}^{\mathrm{m}} \mathrm{c}_{\mathrm{ij}}^{2}}}
$$

$\mathrm{Na}$ osnovu podataka za ovaj primer, dobija se sledeća normalizovana matrica odlučivanja (tabela 3.):

Tabela 3. Normalizovana matrica odlučivanja

\begin{tabular}{|c|c|c|c|c|c|}
\hline Alternative/Kriterijumi & C1 & C2 & C3 & C4 & C5 \\
\hline A1 & 0.70014 & 0.70014 & 0.25198 & 0.67612 & 0.11471 \\
\hline A2 & 0.42008 & 0.56011 & 0.37796 & 0.50709 & 0.57354 \\
\hline A3 & 0.14003 & 0.14003 & 0.62994 & 0.16903 & 0.57354 \\
\hline A4 & 0.56011 & 0.42008 & 0.62994 & 0.50709 & 0.57354 \\
\hline
\end{tabular}

\section{II korak:}

Računanje težinske normalizovane matrice odlučivanja.

U ovom koraku donosilac odluke mora da pokaže svoje preferencije prema atributima na osnovu kojih bira jednu od četiri mogućih metoda sanacija. Zatim se računa težinska normalizovana matrica odlučivanja. Matrica izabranih težinskih keoficijenata glasi:

$$
T N=N \cdot T
$$

gde je

$$
T=\left[\begin{array}{cccc}
t_{1} & \cdots & \cdots & 0 \\
\cdots & t_{2} & \cdots & \cdots \\
\cdots & \cdots & \cdots & \cdots \\
0 & \cdots & \cdots & t_{n}
\end{array}\right]
$$

a $\mathrm{N}$ je normalizovana matrica odlučivanja.

Zbir elemenata dijagonalne matrice dodeljenih težina pojedinim atributima (T) mora biti jednak jedinici, odnosno

$$
\sum_{j=1}^{m} t_{j}=1
$$

Množenjem normalizovane matrice i matrice izabranih težinskih koeficijenata dobija se težinska normalizovana matrica odlučivanja (tabela 4.): 
Tabela 4. Težinska normalizvana matrica odlučivanja

\begin{tabular}{|c|c|c|c|c|c|}
\hline Alternative/Kriterijumi & C1 & C2 & C3 & C4 & C5 \\
\hline A1 & 0.17503 & 0.17503 & 0.06299 & 0.06761 & 0.01721 \\
\hline A2 & 0.10502 & 0.14003 & 0.09449 & 0.05071 & 0.08603 \\
\hline A3 & 0.03501 & 0.03501 & 0.15749 & 0.01690 & 0.08603 \\
\hline A4 & 0.14003 & 0.10502 & 0.15749 & 0.05071 & 0.08603 \\
\hline
\end{tabular}

\section{III korak:}

Određivanje skupova saglasnosti (S) i nesaglasnosti (NS).

U ovom koraku upoređuju se parovi akcija. Akcije koje se upoređuju obeležavaju se sa $\mathrm{p}$ i $\mathrm{r}(\mathrm{p}, \mathrm{r}=1,2, \ldots, \mathrm{m}$ i $\mathrm{p} \neq \mathrm{r})$. Prvo se formira skup saglasnosti (Spr) za akcije $a_{p}$ i $a_{r}$ koji se sastoji od svih kriterijuma ( $\mathrm{J}=\mathrm{j} \mathrm{I} \mathrm{j}=1,2, \ldots, \mathrm{n})$, za koje je akcija $\mathrm{a}_{\mathrm{p}}$ poželjnija od akcije $a_{r}$, tj.

$$
S_{p r}=\left(j \mid x_{p j} \geq x_{r j}\right)
$$

Ukoliko postoji kriterijum tipa minimum, znak nejednakosti je suprotan $(\leq)$. Zatim, formira se komplementarni skup nesaglasnosti, za koji važi:

$$
N S_{p r}=\left(j \mid x_{p j} \prec x_{r j}\right)=J-S_{p r}
$$

Ako se ima kriterijum tipa minimum, znak nejednakosti je suprotan (>).

\section{IV korak:}

Određivanje matrice saglasnosti (MS)

Matrica saglasnosti se računa na osnovu skupova saglasnosti, izračunatih u prethodnom koraku. Elemente ove matrice čine indeksi saglasnosti. Njihova vrednost se računa kao suma preferencija (težinskih koeficijenata), koje odgovaraju pripadajućim elementima skupova saglasnosti. Indeks saglasnosti $S_{p r}$ za akcije $a_{p} i a_{r}$ se računa kao:

$$
M S_{p r}=\sum_{j \in S_{p r}} t_{j}
$$

Vrednost $S_{\text {pr }}$ se kreće $u$ intervalu od 0 do 1. Što je vrednost ovog indeksa bliža jedinici to je akcija $a_{p}$ poželjnija od akcije $\mathrm{a}_{\mathrm{r}}$ (prema kriterijumu saglasnosti). Indeksi saglasnosti formiraju matricu saglasnosti, koja na glavnoj dijagonali ima elemente jednake nuli, jer se ne vrši poređenje alternative sa samom sobom. Matrica saglasnosti za ovaj primer glasi (tabela 5.):

Tabela 5. Matrica saglasnosti

\begin{tabular}{|c|c|c|c|c|}
\hline Alternativa A1 & 0 & 0.60000 & 0.60000 & 0.60000 \\
\hline Alternativa A2 & 0.40000 & 0 & 0.75000 & 0.50000 \\
\hline Alternativa A3 & 0.40000 & 0.40000 & 0 & 0.40000 \\
\hline Alternativa A4 & 0.40000 & 0.75000 & 1.0000 & 0 \\
\hline
\end{tabular}

V korak:

Određivanje matrice nesaglasnosti (MNS).

Elemente matrice nesaglasnosti čine indeksi nesaglasnosti, koji se računaju na sledeći način, koristeći matricu TN (težinsku normalizovanu matricu):

$$
M N S_{p r}=\frac{\max _{j \in N S_{p r}}\left|t_{p j}-t_{r j}\right|}{\max _{\substack{j \in J \\ j \in j}}-t_{r j} \mid}
$$

Indeks nesaglasnosti se kreće u intervalu od 0 do 1 i pokazuje za koliko je alternative 
$a_{p}$ manje poželjna od alternative $a_{r}$. Što je indeks nesaglasnosti veći (bliži jedinici) to je, po kriterijumu nesaglasnosti, alternativa $a_{p}$ manje poželjna od alternative $a_{r}$. Indekse nesaglasnosti se računaju na osnovu težinske normalizovane matrice odlučivanja (TN) i skupa nesaglasnosti za posmatrane alternative $\left(\mathrm{NS}_{\mathrm{pr}}\right)$.

Matrica nesaglasnosti je prikazana $\mathrm{u}$ tabeli 6 .

Tabela 6. Matrica nesaglasnosti

\begin{tabular}{|c|c|c|c|c|}
\hline Alternativa A1 & 0 & 0.98300 & 0.67490 & 1.00000 \\
\hline Alternativa A2 & 1.00000 & 0 & 0.59989 & 1.00000 \\
\hline Alternativa A3 & 1.00000 & 1.00000 & 0 & 1.00000 \\
\hline Alternativa A4 & 0.74085 & 0.55571 & 0.00000 & 0 \\
\hline
\end{tabular}

\section{VI korak:}

Određivanje matrice saglasne dominacije (MSD).

Elemente ove matrice se računaju na osnovu vrednosti praga indeksa saglasnosti. Prag indeksa saglasnosti se definiše kao prosečni indeks saglasnosti, koji se računa po sledećoj formuli:

$$
P I S=\sum_{\substack{p=1 \\ p \neq r}}^{m} \sum_{\substack{r=1 \\ p \neq r}}^{m} \frac{M S_{p r}}{m(m-1)}
$$

$\mathrm{Na}$ osnovu dobijene vrednosti prosečnog indeksa saglasnosti može se reći da akcija $a_{p}$ ima šanse da bude poželjnija od akcije $a_{r}$, samo ako njen odgovarajući indeks saglasnosti $\mathrm{MS}_{\mathrm{pr}}$ prevazilazi vrednost prosečnog indeksa saglasnosti. Matrica saglasne dominacije se formira na osnovu sledećeg kriterijuma:

$$
\begin{aligned}
M S D_{p r}=1 & \text { for } & M S_{p r} \geq P I S \\
M S D_{p r}=0 & \text { for } & M S_{p r} \prec P I S
\end{aligned}
$$

Matrica saglasne dominacije je data $u$ tabeli 7 .

Tabela 7. Matrica saglasne dominacije

\begin{tabular}{|l|l|l|l|l|}
\hline Alternativa A1 & 0 & 1 & 1 & 1 \\
\hline Alternativa A2 & 0 & 0 & 1 & 0 \\
\hline Alternativa A3 & 0 & 0 & 0 & 0 \\
\hline Alternativa A4 & 0 & 1 & 1 & 0 \\
\hline
\end{tabular}

\section{VII korak:}

Određivanje matrice nesaglasne dominacije.

Slično kao i u prethodnom koraku, matricu nesaglasne dominacije se računa tako što se prvo izračuna prosečni indeks nesaglasnosti preko relacije:

$$
\text { PINS }=\sum_{\substack{p=1 \\ p \neq r}}^{m} \sum_{\substack{r=1 \\ p \neq r}}^{m} \frac{M N S_{p r}}{m(m-1)}
$$

Matrica nesaglasne dominacije je data u tabeli 8 . 
Tabela 8. Matrica nesaglasne dominacije

\begin{tabular}{|l|l|l|l|l|}
\hline Alternativa A1 & 0 & 0 & 1 & 0 \\
\hline Alternativa A2 & 0 & 0 & 1 & 0 \\
\hline Alternativa A3 & 0 & 0 & 0 & 0 \\
\hline Alternativa A4 & 1 & 1 & 1 & 0 \\
\hline
\end{tabular}

\section{VIII korak:}

Određivanje matrice agregatne dominacije (MAD).

Ova matrica se dobija kao proizvod pozicija elemenata matrice saglasne i matrice nesaglasne dominacije (ne radi se o klasičnom matričnom računu) na sledeći način:

$$
M A D_{p r}=M S D_{p r} \cdot M N S D_{p r}
$$

Matrica agregatne dominacije glasi (tabela 9.):

Tabela 9. Matrica agregatne dominacije

\begin{tabular}{|c|c|c|c|}
\hline $\mathrm{A} 1$ & 0 & 1 & 0 \\
\hline 0 & $\mathrm{~A} 2$ & 1 & 0 \\
\hline 0 & 0 & $\mathrm{~A} 3$ & 0 \\
\hline 1 & 1 & 1 & $\mathrm{~A} 4$ \\
\hline
\end{tabular}

\section{IX korak:}

Eliminisanje manje poželjnih akcija.

Ukoliko je vrednost $\mathrm{MAD}_{\mathrm{pr}}=1$, tada akcija $a_{p}$ dominira nad akcijom $a_{r}$, po oba kriterijuma (saglasnosti i nesaglasnosti). Ali to ne znači da ne postoji neka druga alternativa koja ne dominira nad $a_{p}$. Zbog toga je potrebno da bude zadovoljen još jedan uslov:

$\mathrm{MAD}_{\mathrm{pr}}=1$ za bar jedno $\mathrm{r}, \mathrm{r}=1,2, \ldots$, $\mathrm{m}$ i $\mathrm{p} \neq \mathrm{r}$ $\mathrm{i} \neq \mathrm{r}$

$\mathrm{MAD}_{\mathrm{pr}}=0$ za sve i, i $=1,2, \ldots, \mathrm{m}$ i p $\neq \mathrm{r} \mathrm{i}$

Dobijeni rezultati izvršene višekriterijumske analize ukazuju na sledeće:

- A1 dominira nad: A3

- A2 dominira nad: A3

- A3 ne dominira ni nad jednom akcijom

- A4 dominira nad: A2 A3

- Najbolja alternativa: A4.

Rezultati pokazuju da je najbolja alternativa A4 (formiranje neutralne tampon zone), zatim slede alternative A1 (duboko zaoravanje) i A2 (reciklaža), a na poslednjem mestu je alternativa A3 (uklanjanje nanosa).

\section{ANALIZA DOBIJENIH REZULTATA}

Optimalna alternativa A4, odnosno metoda sanacije koja podrazumeva formiranje neutralne tampon zone iznad nanosa flotacijske jalovine od kreča i nasipavanje humusne zemlje iznad ove tampon zone ima najviše ocene $\mathrm{u}$ odnosu na ostale sa aspekta kriterijuma C3 (dobijeni - očekivani rezultati) i C5 (univerzalnost metode). Takođe, ova metoda je na drugom mestu što se tiče kriterijuma C1 (mogućnost tehničke realizecije sanacije), a na sredini je u odnosu na ostale metode što se tiče kriterijuma C2 (troškovi sanacije) i C4 (trajanje sanacije). To pokazuje da ova metoda, nakon njene realizacije, obezbeđuje nesmetano korišćenje saniranog zemljišta za gajenje raznih kultura koje se mogu koristiti za ishranu 
ljudi i životinja, zatim ona se može koristiti za potpunu sanaciju svih degradiranih površina, bez obzira na njihov stepen degradacije, tehnički nije komplikovana za izvođenje i troškovi i vreme potrebni za njenu realizacije su umereni u odnosu na druge predložene metode sanacije.

Alternativa A1 (duboko zaoravanje nanosa flotacijske jalovine) je rangirana na drugom mestu. Ona ima najviše ocene što se tiče kriterijuma $\mathrm{C} 1$ i C2 i C4 u odnosu na ostale metode, ali ima najniže ocene sa aspekta kriterijuma C3 i C5. To ukazuje na to da je ona najlakša za realizaciju, najjeftinija je i zahteva najkraće vreme realizacije. Sa druge strane, ova metoda daje najslabije očekivane rezultate jer sanirano zemljište ne može da se koristi za gajenje kultura za ishranu ljudi i životinja zbog mešanja nanosa flotacijske jalovine sa humusom i nije primenljiva na svim degradiranim površinama, naročito tamo gde je nanos flotacijske jalovine deblji od $90 \mathrm{~cm}$.

Alternativa A2 (reciklaža nanosa flotacijske jalovine) je rangirana na trećem mestu. Ona i štoma najviše ocene se tiče kriterijuma $\mathrm{C} 5$, na drugom mestu je što se tiče kriterijuma $\mathrm{C} 2$, a na sredini je aspekta ostala tri kriterijuma (C1, C3 i C4). To pokazuje da ova metoda može efikasno da se koristi na svim degradiranim površinama, umerena je sa aspekta troškova i vremena realizacije, srednje komplikovana za realizeciju i daje dobre rezultate.

$\mathrm{Na}$ kraju, alternativa A3 (uklanjanje nanosa flotacijske jalovine sa kontiminiranog zemljišta) je rangirana na poslednjem, četvrtom mestu. Ona ima najviše ocene što se tiče kriterijuma C3 i C5, a najniže je ocenjena u odnosu na kriterijume $\mathrm{C} 1, \mathrm{C} 2$ i C4. To pokazuje da ova metoda obezbeđuje potpunu sanaciju degradiranog zemljišta $i$ vrhunske očekivane rezultate, kao i to da se ona može koristiti za sanaciju celokupne degradirane površine. Sa druge strane, ova metoda je tehnički najteža za realizaciju (zahteva složenu i skupu opremu i tehnologiju), najskuplja je i zahteva najduže vreme za realizaciju u odnosu na ostale metode sanacije.

\section{ZAKLJUČAK}

U ovom radu, primenjena je višekriterijumska metoda donošenja odluke u cilju izbora optimalne metode sanacije degradiranih površina obale Borske reke. Izbor optimalne metode sanacije degradiranih površina obale Borske reke je jedna od najznačajnijih odluka u toku upravljanja projektom revitalizacije uništenih i zagađenih površina koje su nastale dugogodišnjim rudarenjem na ovom području. Pri tome, razmatrane su četiri moguće metode sanacije - duboko zaoravanje površina prekrivenih slojem flotacijske jalovine (alternativa A1), reciklaža nanosa flotacijske jalovine (alternativa A2), uklanjanje nanosa flotacijske jalovine sa kontiminiranog zemljišta (alternativa A3) i formiranje neutralne tampon zone iznad nanosa flotacijske jalovine od kreča i nasipavanje humusne zemlje iznad ove tampon zone (alternativa A4). Sam proces izbora zahteva razmatranje brojnih kriterijuma kao što su mogućnost tehničke realizacije procesa sanacije (kriterijum $\mathrm{C} 1$ ), troškovi sanacije (kriterijum C2), očekivani rezultati sanacije (kriterijum C3), trajanje sanacije (kriterijum C4) i univerzalnost primenjene metode sanacije (kriterijum C5). Izbor optimalne metode sanacije vrši se na osnovu upoređenja primenljivih metoda u skladu sa odgovarajućim kriterijumima.

Shodno tome, u radu je korišćena ELECTRE metoda odlučivanja. Kod ovog pristupa, prvo se vrši određivanje težinskih koeficijenata kriterijuma za izbor optimalne metode sanacije, a onda ocenjivanje predloženih metoda i njihovo kompletno rangiranje.

Predložena metoda za donošenje odluke može biti od velike pomoći donosiocima odluka, jer omogućava laku analizu uticajnih faktora i parametara. Shodno tome, na osnovu dobijenih rezultata ELECTRE 
metodom, izabrana je najbolja metoda sanacije, a to je formiranje neutralne tampon zone iznad nanosa flotacijske jalovine od kreča i nasipavanje humusne zemlje iznad ove tampon zone (alternativa A4). Najuticajniji kriterijumi za kompletno rangiranje alternativa (metoda sanacije) su mogućnost tehničke realizacije (kriterijum $\mathrm{C} 1$ ), troškovi (kriterijum C2) i dobijeni (očekivani) rezultati (kriterijum C3).

\section{LITERATURA}

[1] Komnitsas K., Baptzas G., Paspaliaris I., Clean Up of Acidic Leachates Using Fly Ash Barriers: Laboratory Column Studies, Proc. $8^{\text {th }}$ Int. Conf. on Environmental Science and Technology, Lemnos Island (2003).

[2] Komnitsas K., Lazar I., Petrisor I., Application of a vegetative cover on phosphogypsum stacks, Minerals Engineering, 12 (1999) 175-185.

[3] Komnitsas K., Xenidis A., Tabouris S., Composite cover for the prevention of acid mine drainage, Mining Enviromental Management, 8 (2000) 14-17.
[4] Peppass A., Komnitsas K., Halikia I., Use of organic covers for acid mine drainage control, Minerals Engineering, 13 (2000) 563-574.

[5] Bufardi A., Gheorghe R., Kiritsis D. and Hirouchakis P., Multicriteria decision-aid approach for product endof-life alternative selection, International Journal of Production Research, 42 (2004) 3139-3157.

[6] Roy B., The outranking approach and the foundation of electre methods, Theory Decision 31 (1991) 49-73.

[7] Council Directive, (1999), Directive 1999/31/EC of the European Parliament and of the Council of 26 April 1999 on the landfill of waste, Official Journal of the European Communities, OJ L 182, 16.07.1999, Brussels.

[8] EC Directive (2008), Directive 2008/98/EC of the European Parliament and of the Council of 19 November 2008, on waste and repealing certain Directives, Official Journal of the European Communities, L312/3, 22.11.2008, Brussels. 